\title{
Multi Peran Guru di SMP Negeri 1 Konawe Selatan (Antara Kinerja dan Panggilan Moral)
}

\author{
Sandra Hasba \\ Pascasarjana Universitas Halu Oleo \\ email: hasba25@gmail.com
}

\begin{abstract}
Abstrak
Artikel ini bertujuan memberikan gambaran tentang peranperan guru dalam peningkatan kinerja di SMP Negeri 1 Konawe Selatan, yang meliputi: 1) Peran guru dalam menciptakan iklim belajar; 2) Faktor yang memengaruhi kinerja guru; 3) Potret guru di SMP Negeri 1 Konawe Selatan; 4) peran kepala sekolah dalam peningkatan kinerja guru. Penelitian ini menggunakan jenis penelitian kualitatif-deskriptif, dimana proses pengumpulan data dilakukan melalui wawancara, pengamatan, dan studi dokumentasi. Analisis data dilakukan melalui tahap reduksi, display, dan verifikasi data. Hasil penelitian menunjukkan bahwa iklim belajar di SMP Negeri 1 Ranomeeto tercipta karena keterlibatan yang tinggi dari para guru. Faktor kemampuan, motivasi dan keterampilan sangat memengaruhi kinerja guru di SMP Negeri 1 Konawe Selatan. Peran-peran keguruan yang dilakukan oleh para guru di SMP Negeri 1 Konawe Selatan telah melampaui kewajiban kinerja mereka. Kepala sekolah menjadi penggerak dalam perluasan peran dan peningkatan kinerja guru di SMP Negeri 1 Konawe Selatan.
\end{abstract}

Kata Kunci: Kinerja, Kompetensi Guru, Kepemimpinan 
Multi Role Teachers in SMP Negeri 1 Konawe Selatan (Between Performance and Moral Vocation)

\author{
Sandra Hasba \\ Pascasarjana Universitas Halu Oleo \\ email: hasba25@gmail.com
}

\begin{abstract}
This article aims to provide an overview of the roles of teachers in improving performance in SMP Negeri 1 Konawe Selatan, which includes: 1) The role of teachers in creating a learning climate; 2) Factors that affect teacher performance; 3) Portrait of the teacher at SMP Negeri 1 Konawe Selatan; 4) the role of the principal in improving teacher performance. This research uses descriptive qualitative research, where the process of collecting data is done through interviews, observations, and documentation studies. Data analysis is performed through the stages of reduction, display, and data verification. The results showed that the learning climate in SMP Negeri 1 Ranomeeto was created because of the high involvement of the teachers. The ability, motivation and skill factors greatly affect the performance of teachers in SMP Negeri 1 Konawe Selatan. Teacher roles performed by teachers in SMP Negeri 1 Konawe Selatan have exceeded their performance obligations. The headmaster became a mover in expanding roles and improving teacher performance in SMP Negeri 1 Konawe Selatan.
\end{abstract}

Keywords: Performance, Teacher Competence, Leadership 


\section{Pendahuluan}

Kinerja sering disebut sebagai prestasi kerja (job performance), juga sebagai prestasi kerja sesungguhnya (actual performance $)^{1}$, berdasarkan pada tanggung jawab yang diberikan kepada seseorang ${ }^{2}$. Sehingga dapat dikatakan bahwa kinerja merupakan prestasi kerja dari seseorang berdasarkan tanggung jawabnya dibandingkan dengan standar pada tempat ia bekerja.

Kinerja dipengaruhi oleh faktor kemampuan dan motivasi ${ }^{3}$. Sedang dimensi kinerja mencakup target, kualitas, waktu penyelesaian, dan taat asas ${ }^{4}$. Adapun indikator kinerja antara lain ketepatan penyelesaian tugas, kesesuaian jam kerja, tingkat kehadiran, kerjasama antar karyawan, dan kepuasan kerja ${ }^{5}$.

Secara faktual, pemenuhan berbagai aspek tentang kinerja tidaklah cukup untuk menciptakan kualitas tinggi, terkhusus pada lembaga pendidikan. Dalam konteks guru, mereka dihadapkan pada tuntutan tidak hanya pada domain tanggung jawab profesional mereka. Lebih dari itu menuntut keterlibatan mereka dalam berbagai agenda sekolah, juga kiprah di masyarakat luas. Menarik melihat peran-peran guru di SMP Negeri 1 Konawe Selatan yang melampaui kewajiban kinerja.

Oleh karena itu, artikel ini merupakan upaya menjelaskan kinerja guru di SMP Negeri 1 Konawe Selatan yang meliputi perang guru dalam menciptakan iklim belajar, faktor yang memengaruhi kinerja, potret guru di SMP Negeri 1 Konawe Selatan, dan peran kepala sekolah dalam peningkatan kinerja guru.

${ }^{1}$ Pramudyo, A. (2010). Analisis faktor-faktor yang mempengaruhi kinerja dosen negeri pada kopertis Wilayah V Yogyakarta. Jurnal Bisnis: Teori dan Implementasi, 1(1), 1-11.

${ }^{2}$ Febriyanti, B. M., \& Faslah, R. (2013). Hubungan Antara Beban Kerja Dengan Kinerja Pada Karyawan Balai Permasyarakatan Kelas I Jakarta Selatan (BAPAS) di Jakarta Timur. Jurnal Pendidikan Ekonomi Dan Bisnis (JPEB), 1(2), 104-116.

${ }^{3}$ Wardana, D. S. (2013). Motivasi berprestasi dengan kinerja guru yang sudah disertifikasi. Jurnal Ilmiah Psikologi Terapan, 1(1), 98-109.

${ }^{4}$ Danuputra, F., \& Sary, F. P. (2019). Pengaruh Dimensi Knowledge Sharing Terhadap Kinerja Karyawan (studi Pada Karyawan Non-dosen Universitas Telkom Bandung). eProceedings of Management, 6(2).

${ }^{5}$ Widayaningtyas, R. (2016). Pengaruh Disiplin Kerja dan Motivasi Kerja terhadap Kinerja Karyawan (Studi Pada PT. Macanan Jaya Cemerlang Klaten). Jurnal Manajemen Bisnis Indonesia (JMBI), 5(5), 527-537. 


\section{Metode}

Penelitian ini merupakan penelitian deskriptif-kualitatif yang menggunakan teknik observasi, wawancara dan dokumentasi dalam proses pengumpulan data ${ }^{6}$. Proses analisis data menggunakan model dari Miles dan Huberman, yaitu reduksi data, display data, dan verifikasi data ${ }^{7}$. Pengujian keabsahan data melalui proses trianggulasi, perpanjangan pengamatan dan peningkatan ketekunan ${ }^{8}$.

\section{Hasil dan Pembahasan}

\section{A. Peran Guru dalam Iklim Belajar di SMP Negeri 1 Konawe Selatan}

SMP Negeri 1 Konawe Selatan lingkunganya sangat bersih dan tertata sangat rapi dan pemadangan nya sangat bagus baik dilihat baik dari dalam mau pun dari luar sekolah. Dari segi sarana penunjang pembelajaran seperti komputer, sejak 2017 telah mencukupi kebutuhan siswa. Lingkukan sekolah ini terpisah dari jalan raya sehingga proses belajar mengajar dapat dilalui oleh siswa dengan penuh konsentrasi.

Pada tahun 2016 SMP Negeri 1 Konawe Selatan adalah sekolah yang mendapatkan kunjungan dalam rangka sosialisasi penelitian arkeologi di Sulawesi tenggara. Kegiatan sosialisasi dihadiri oleh kepala sekolah, guru-guru, dan siswa. Tujuannya sosialisasi adalah memaparkan hasil-hasil penelitian arkeologi di situs lapangan terbang Kendari II. Kegiatan ini mendapat respon positif oleh siswa yang secara antusias mengajukan pertanyaan seputar periode perang fisik dan peninggalan-peninggalan Jepang. Di samping itu, adapula siswa yang memberikan beberapa informasi tentang keberadaan bungker di lingkungan sekitar rumahnya.

Kegiatan rutin setiap jum'at adalah pelaksanaan jum'at bersih. Kegiatan ini untuk memastikan kondisi lingkungan sekolah terjaga kebersihannya, teratur, dan tertata baik. Informasi dari masyarakat sekitar menyebutkan bahwa kondisi lingkungan yang bersih di SMP Negeri 1 Konawe Selatan berkat kepala sekolah yang selalu

${ }^{6}$ Bungin, B. (2007). Penelitian kualitatif: komunikasi, ekonomi, kebijakan publik, dan ilmu sosial lainnya. Kencana.

${ }_{8}^{8}$ Sugiyono, P. Dr. 2010. Metode Penelitian Kuantitatif, Kualitatif, dan
R\&D. Bandung: CV Alfabeta.

7 Miles, M. H., \& Huberman, A. A. 1984. Qualitative Data Analysis. 
menanamkan budaya kebersihan kepada siswa, dan seluruh warga sekolah. Bahkan masyarakat juga sering diajak untuk bersama-sama dalam kegiatan jum'at bersih.

Terkait dengan kebersihan sekolah, terdapat peraturan sekolah yang memberi denda terhadap pelanggar kebersihan, misalnya membuang sampah bukan pada tempat pembuangan akan di kenakan denda satu sampah seribu rupiah. Peraturan ini tidak hanya menyasar siswa tetapi juga guru, tenaga kependidikan, bahkan kepala sekolah.

Iklim belajar merupakan kemestian pada lembaga pendidikan, juga harus menjadi bagian dari budaya sekolah ${ }^{9}$. Kelas-kelas mesti didesain agar siswa nyaman dan betah di dalamnya, tentu saja untuk membelajarkan. Suasana kelas diciptakan sedemikian rupa agar mendorong peserta didik berlomba dalam belajar dan mengejar prestasi ${ }^{10}$. Iklim belajar juga akan memengaruhi perkembangan kedisiplinan siswa ${ }^{11}$, akan tetapi harus dimulai dengan pengelolaan kelas yang baik oleh guru ${ }^{12}$.

\section{B. Faktor-Faktor Yang Memengaruhi Kinerja Guru di SMP Negeri 1 Konawe Selatan}

Kinerja guru di SMP Negeri 1 Konawe Selatan dipengaruhi oleh berbagai faktor. Di samping faktor lingkungan sekolah, pergaulan dengan warga sekolah, juga ketersediaan sarana prasarana pendidikan. Beberapa fakta yang dapat ditunjukkan terkait faktor-faktor tersebut dapat dilihat pada uraian berikut. Salah satu yang menonjol dalam perilaku guru di SMP Negeri 1 Konawe Selatan adalah keakraban siswa dengan guru. Kondisi ini terkadang dipersepsikan sebagai perilaku yang berlebihan dalam pergaulan murid dan guru, bahkan dianggap tidak etis. Akan tetapi, para guru berpandangan bahwa untuk

${ }^{9}$ Fiteriani, I. (2015). Membudayakan Iklim Semangat Belajar Pada Siswa Sekolah Dasar. TERAMPIL: Jurnal Pendidikan dan Pembelajaran Dasar, 2(1), 11525.

${ }^{10}$ Hadinata, P. (2012). Iklim kelas dan motivasi belajar siswa SMA. Jurnal psikologi, 3(1).

11 Nugraha, Y. (2015). Pengaruh Kinerja Guru PKn dan Iklim Belajar Terhadap Perkembangan Sikap Disiplin Peserta Didik (Studi Survey Pada Sekolah Menengah Pertama Negeri di Kabupaten Karawang) (Doctoral dissertation, Universitas Pendidikan Indonesia).

${ }^{12}$ Apriliya, S. (2007). Manajemen Kelas untuk Menciptakan Iklim Belajar yang Kondusif. Bandung: Visindo. 
dapat mendidik siswa, perlu diciptakan suasana akrab dan penuh kekeluargaan. Bahwa para siswa membutuhkan perhatian, bukan menciptakan ketakutan.

Ketersediaan sarana prasarana pendidikan di SMP Negeri 1 Konawe Selatan menjadi kegelisahan bersama, sehingga muncul keinginan agar dapat dipenuhi. Para guru merasakan bahwa perkembangan teknologi informasi dan komunikasi tentu berimbas dalam praktik pembelajaran. Sebenarnya bisa saja mereka mempertahankan praktik pembelajaran yang serba manual, akan tetapi hal ini menunjukkan bahwa mereka tidak cukup kompetitif menyambut era kekinian. Karenanya muncul usulan untuk meningkatkan kuantitas maupun kualitas sarana prasarana pendidikan di SMP Negeri 1 Konawe Selatan.

Perilaku guru juga masih banyak menampilkan gaya klasik dalam menghadapi siswa, seperti menyerahkan kegiatan belajar pada salah seorang siswa yang dimodali dengan buku paket. Praktik ini menunjukkan rendahnya tanggung jawab guru dalam pembelajaran, juga mencerminkan kepekaan yang rendah terhadap kondisi siswa. Hal ini tentu bertentangan dengan semangat sekolah yang ingin tampil kompetitif dengan sekolah lain.

Meskipun demikian, tradisi lain yang mengimbangi praktik negatif di atas adalah pembiasaan budaya hemat energi yang dipelopori oleh guru. Beberapa ruangan yang memiliki AC (air conditioner) di atur sedemikian rupa sehingga hanya digunakan pada saat-saat tertentu saja, tidak setiap saat. Kebiasaan ini mendapat dukungan dari pimpinan SMP Negeri 1 Konawe Selatan. Tradisi lain yang dikembangkan adalah kepedulian terhadap lingkungan. Sejalan dengan agenda sekolah yang secara tegas menyatakan komitmen yang tinggi terhadap penyelamatan lingkungan, maka para guru mendorong suasana sekolah yang bersih. Peserta didik tidak hanya mendapatkan perintah untuk hidup bersih, tetapi dilibatkan dalam kegiatan-kegiatan peduli lingkungan sekolah. Bahkan diadakan perlombaan pada tingkat siswa terkait dengan kepedulian terhadap lingkungan. Selain itu, siswa juga dilibatkan dalam kunjungan ke masyarakat sekitar dalam sosialisasi lingkungan yang sehat. 
Kinerja guru dipengaruhi oleh faktor pengetahuan atau kemampuan, motivasi, dan keterampilan ${ }^{13}$. Pengetahuan ataupun kemampuan biasanya berhubungan dengan kualifikasi pendidikan dan pengalaman ${ }^{14}$. Sedangkan motivasi terkait dengan faktor kesadaran maupun faktor-faktor eksternal yang menyebabkan terciptanya kinerja seorang guru. Di dalamnya menyangkut tanggung jawab, imbalan, dan kepuasan kerja ${ }^{15}$. Sedangkan keterampilan berhubungan dengan kemampuan seorang guru dalam melakukan pekerjaan yang bersifat konseptual maupun teknis dengan baik. Biasanya keterampilan diperoleh melalui pendidikan khusus, kursus, dan pelatihan ${ }^{16}$.

Dalam konteks kualifikasi akademik, guru-guru di SMP Negeri 1 Konawe Selatan telah memiliki kualifikasi yang sesuai standar peraturan perundang-undangan tentang kualifikasi minimal seorang guru. Bahkan sebagian besar guru telah memiliki sertifikat pendidik. Jika secara faktual para guru di SMP Negeri 1 Konawe Selatan belum menunjukkan kinerja sesuai harapan, tentu hal ini perlu diperbaiki dari segi peningkatan kualitas melalui latihan-latihan. Persoalan sertifikasi guru memang belum secara otomatis menjadi jaminan profesionalitas ${ }^{17}$.

13 Indrawati, Y. (2006). Faktor-faktor yang mempengaruhi kinerja guru matematika dalam pelaksanaan kurikulum berbasis kompetensi (kbk) pada sekolah menengah atas Kota Palembang. Jurnal Manajemen \& Bisnis Sriwijaya, 4(7), 41-58.

${ }^{14}$ Awe, E. Y., Dantes, N., \& Lasmawan, M. P. P. I. W. (2019). Hubungan Antara kualifikasi akademik, kompetensi, motivasi kerja dengan kinerja guru sekolah dasar (SD) di Kecamatan Bajawa, Kabupaten Ngada (Doctoral dissertation, Ganesha University of Education).

${ }^{15}$ Zulkifli, M., Darmawan, A., \& Sutrisno, E. (2014). Motivasi Kerja, Sertifikasi, Kesejahteraan dan Kinerja Guru. Persona: Jurnal Psikologi Indonesia, $3(02)$.

${ }^{16}$ Hasanah, D. S., Fattah, N., \& Prihatin, E. (2010). Pengaruh Pendidikan Latihan (Diklat) Kepemimpinan Guru dan Iklim Kerja Terhadap Kinerja Guru Sekolah Dasar Se Kecamatan Babakancikao Kabupaten Purwakarta. Jurnal Penelitian Pendidikan, 11(2), 90-105.

${ }^{17}$ Murwati, H. (2012). Pengaruh sertifikasi profesi guru terhadap motivasi kerja dan kinerja guru di smk negeri se-Surakarta. Lihat pula BUYUNG NASUTIYON, W. I. S. N. U. (2010). Pengaruh Sertifikasi Guru terhadap Kompetensi Mengajar Guru Sekolah Dasar Negeri di Kecamatan Benjeng Kabupaten Gresik. Jurnal Mahasiswa Teknologi Pendidikan, 1(1). 


\section{Potret Guru di SMP Negeri 1 Konawe Selatan: Melampaui Kinerja}

Wilayah tugas guru tidak hanya dalam konteks tugas-tugas profesi guru an sich, tetapi terkadang lebih luas dari itu. Apalagi jika dikaitkan dengan tuntutan sebagian masyarakat yang memandang guru harus dapat menyentuh berbagai persoalan peserta didik, tidak hanya di dalam kelas. Dalam uraian ini akan diketengahkan peranperan guru di SMP Negeri 1 Konawe Selatan di luar tanggung jawab profesionalnya.

Salah satu persoalan yang menyeret guru dalam penyelesaiannya adalah perkelahian antar siswa, ataupun perilaku kekerasan yang dilakukan oleh siswa terhadap siswa yang lain. Atas peristiwa tersebut, beban penyelesaian masalah selalu dibebankan kepada guru. Apalagi guru-guru yang memegang tanggung jawab pada kelas-kelas tertentu sebagai wali kelas. Tugas mereka melakukan penyelidikan terkait asal masalah hingga cara-cara penyelesaian masalah.

Peristiwa di atas mendapat respon dari orang tua siswa dan ikut serta melakukan pengawasan terhadap anak-anak mreka. Misalnya, siswa-siwa di sini ketika berangkat kesekolah selalu diantar oleh orang tuanya masing-masing. Alasannya pada saat mengantar dan menjemput dapat memantau lingkungan sekolah dan perilaku anak mereka. Meskipun demikian, peristiwa-peristiwa yang terjadi antar siswa sulit dihindarkan. Sehingga para guru harus lebih aktif melakukan pemantauan atas berbagai perilaku siswa selama berada di lingkungan sekolah.

Perbaikan kinerja guru memerlukan dukungan berbagai aspek. Di samping komitmen kepala sekolah, pada saat yang sama ketersediaan sarana prasarana yang mendukung juga penting diperhatikan. Kondisi sarana prasarana di SMP Negeri 1 Konawe Selatan membutuhkan peningkatan dari segi kualitas dan kuantitas. Misalnya ketersediaan media pembelajaran yang selaras dengan kemajuan teknologi informasi dan komunikasi. Terlebih jika dikaitkan dengan semangat 4.0, maka sarana prasarana di sekolah ini perlu dipikirkan secara serius.

Praktik pembelajaran juga memerlukan perbaikan-perbaikan di SMP Negeri 1 Konawe Selatan. Penyajian pembelajaran belum banyak menunjukkan adanya inovasi dan ujicoba atas berbagai teknik dan strategi pembelaran yang sedang berkembang. Menurut 
penjelasan kepala sekolah, para guru secara rutin mengikuti kegiatan peningkatan kompetensi profesional. Tetapi latihan-latihan yang diikuti belum dapat diterapkan dalam kegiatan pembelajaran secara berkelanjutan.

Persoalan susulan yang penting diperhatikan adalah pengembangan kurikulum. Model pengembangan kurikulu yang di gunakan di SMP Negeri 1 Konawe Selatan adalah model administratif yaitu atasan membentuk tim yang terdiri dari beberapa oarng pejabat. Tim membuat rumusan tujuan umum dan dibentuk pula beberapa kelompok kerja yang terdiri dari guru guru yang sudah perpengalaman dalam mengembangkan kurikulum untuk memutuskan tujuan kurikulum tersebut dan menyusun materi, kegiatan pembelajaran dan sisitem penilaian hasil kerja. Kemudian direvisi oleh tim atas dasar pengalaman atau hasil dari try out system, kemudian di terapkan di lembaga pendidikan.

Kinerja guru sesungguhnya menyangkut kompetensinya dalam bidang pedagogik, profesional, sosial, dan kepribadian ${ }^{18}$. Tugas-tugas yang dilakukan di luar keempat kompetensi di atas dapat dianggap sebagai tambahan saja, bukan kewajiban, melainkan sebagai panggilan moral. Karena ada anggapan bahwa seorang guru akan tetap menjadi guru, kapan pun dan di mana pun.

Seorang guru pada umumnya memiliki pemahamanpemahaman yang cukup baik tentang masalah-masalah pendidikan, sebelum beranjak pada persoalan stategi dan teknik mengajar. Mereka adalah pribadi-pribadi yang sadar akan pendidikan dan pentingnya mendidik manusia. Karenanya mereka belajar memahami dimensidimensi manusia yang menjadi subjek ajar. Para guru umumnya memiliki pengetahuan-pengetahuan dasar tentang pendidikan dan pengajaran, atau pedagogik ${ }^{19}$.

Kesiapan personal adalah aspek penting selain kesiapan secara pedagogik. Pilihan menjadi guru merupakan jalan hidup, sehingga orientasi mereka adalah untuk mencerdaskan kehidupan bangsa, mengikuti anjuran Ki Hajar Dewantara tentang ing madya mangun

18 Sauri, S. (2010). Membangun karakter bangsa melalui pembinaan profesionalisme guru berbasis pendidikan nilai. Jurnal Pendidikan Karakter, 2(2), 115 .

${ }^{19}$ Suhandani, D., \& Julia, J. (2014). Identifikasi Kompetensi Guru Sebagai Cerminan Profesionalisme Tenaga Pendidik Di Kabupaten Sumedang (Kajian Pada Kompetensi Pedagogik). Mimbar Sekolah Dasar, 1(2), 128-141. 
karso, ing ngarso sung tulodo, tut wuri handayani ${ }^{20}$. Para guru memiliki kedalaman batin terkait dengan pencerdasan peserta didik, terkoneksi dengan perasaan peserta didik. Kondisi ini membuat mereka dapat mencurahkan segala upaya untuk kepentingan peserta didik. Secara fisik, para guru perlu menunjukkan penampilan sebagai guru dalam konteks membangun kewibawaan mereka di hadapan peserta didik ${ }^{21}$. Pembawaan pribadi yang fokus pada pengembangan peserta didik menjadikan para guru sebagai subjek yang dicintai oleh peserta $\operatorname{didik}^{22}$.

Tuntutan profesionalisme yang semakin kuat, mengharuskan para guru untuk bekerja secara teratur, tertata, terencana, dan sistematik. Secara administratif maupun substantif, peran-peran keguruan mesti dapat diterapkan, terutama dalam interaksi di dalam kelas. Inovasi-inovasi mesti dilakukan oleh para guru, terutama menghadirkan kegiatan pembelajaran yang senafas dengan kemajuan teknologi informasi dan komunikasi. Para guru harus selalu tertantang untuk menguji coba pendekatan-pendekatan pembelajaran melakukan kegiatan penelitian tindakan kelas. Cara ini lebih dapat mendekatkan kepentingan guru dan peserta didik ${ }^{23}$. Selain itu, membiasakan diri dalam pembelajaran era digital ${ }^{24}$, memahami problem-problem belajar peserta didik dan melakukan tindakan pemecahan masalah ${ }^{25}$.

Pergaulan guru melibatkan berbagai komponen sekolah, baik itu pimpinan, peserta didik, tenaga kependidikan, dan masyarakat luas

${ }^{20}$ Susilo, S. V. (2018). Refleksi nilai-nilai pendidikan ki hadjar dewantara dalam upaya upaya mengembalikan jati diri pendidikan indonesia. Jurnal Cakrawala Pendas, 4(1).

21 Milkan, A. (2018). Pengaruh Kewibawaan Guru Pendidikan Agama Islam Terhadap Akhlak Siswa Di Sekolah Menengah Atas Negeri 2 Tualang Kabupaten Siak (Doctoral dissertation, Universitas Islam Negeri Sultan Syarif Kasim Riau).

22 Rochman, C., \& Gunawan, H. (2011). Pengembangan Kompetensi kepribadian guru: Menjadi guru yang dicintai dan diteladani oleh siswa. Bandung: Nuansa Cendekia.

${ }^{23}$ Sastramayani, S. (2018). Mempertemukan Semesta Guru dan Peserta Didik dalam Metode Pembelajaran Kooperatif. Shautut Tarbiyah, 24(2), 308-333.

${ }^{24}$ Sastriyani, S. (2018). Dinamika Pembelajaran PAI di Era Digital (Studi di MTsN Wawotobi, Kabupaten Konawe). Shautut Tarbiyah, 24(1), 145-162.

${ }^{25}$ Syahrul, S. (2015). Dinamika Pembelajaran Metodologi Penelitian Pada Mahasiswa Jurusan Tarbiyah Stain Kendari. Al-Izzah: Jurnal Hasil-Hasil Penelitian, 8(1), 193-211. 
dalam hal ini orang tua peserta didik. Karenanya, para guru dituntut untuk dapat melakukan peran-peran sosial tersebut dengan baik. Citra para guru akan mudah dibentuk dalam konteks relasi sosial mereka. Kemampuan komunikasi sangat dibutuhkan, selain itu kemampuan membawa diri secara bijak dalam pergaulan dengan warga sekolah maupun masyarakat luas ${ }^{26}$.

\section{Peran Kepala Sekolah dalam Meningkatkan Kinerja Guru di SMP Negeri 1 Konawe Selatan}

Perbaikan kinerja guru tidak muncul begitu saja, tetapi melalui sokongan pimpinan sekolah, dalam hal ini kepala sekolah. Praktik yang ditampilkan oleh kepala sekolah adalah melalui cara-cara yang sederhana, misalnya memberikan pujian, menyampaikan rasa terima kasih, selalu menyapa, dan mendorong berpikir positif. Hal ini tergambar dari temuan berikut:

Pemimpin SMP Negeri 1 Konawe Selatan selalu memberikan sapaan, pujian, dan ucapan terima kasih kepada guru dan staf sekolah. Kepemimpinan yang ada dilandasi oleh asumsi yang positif dari karyawan. Sebab prasangka yang negatif dapat menjadikannya bersikap buruk terhadap bawahan ${ }^{27}$.

Sikap kepala sekolah di atas juga diturunkan dalam praktik pengelolaan sekolah, sebagaimana tergambar dalam hasil wawancara berikut:

Dalam berbagai kegiatan, kepala sekolah melakukan pemberdayaan semua potensi sekolah. Selain itu, agar kegiatan berlangsung secara efektif dan efisien, maka selalu diarahkan pada pencapaian visi dan misi sekolah. Pimpinan juga mendorong warga sekolah untuk melakukan perubahan, menciptakan kekompakan internal dan membina kerja sama di luar $^{28}$.

Persepsi guru terkait kepemimpinan kepala sekolah terhadap kinerja guru di SMP Negeri 1 Konawe Selatan cukup positif. Para guru mengakui bahwa gaya kepemimpinan yang diterapkan oleh

${ }^{26}$ Ashsiddiqi, H. (2012). Kompetensi sosial guru dalam pembelajaran dan pengembangannya. Ta'dib: Journal of Islamic Education (Jurnal Pendidikan Islam), 17(01), 61-71.

${ }^{27}$ Wawancara, 11 Februari 2019

${ }^{28}$ Wawancara, 11 Februari 2019 
kepala sekolah sangat tepat dalam mendorong peningkatan kinerja guru. Para guru berharap kondisi ini tetap dipertahankan dimana pemimpin dapat menyesuaikan diri dengan situasi bawahan. Gaya kepemimpinan yang diterapkan saat ini dapat memberikan sumbangan yang sangat berarti bagi pembinaan hubungan-hubungan antar individu dalam rangka peningkatan kualitas kerja.

Peran kepala sekolah sebagaimana dijelaskan di atas, merupakan cerminan dari pandangan sekolah pemimpin. Pandanganpandangan kepala SMP Negeri 1 Konawe Selatan dapat disimak sebagai berikut:

Seorang pemimpin harus mempunyai kemampuan manajemen.

Kepemimpinan tidak hanya hubungan dengan bawahannya, melainkan bagaimana seorang pemimpin mampu menjadi pengendali bagi keberlangsungan organisasi yang dipimpinnya yaitu kemampuan memimpin dalam mengadakan pengawasan terhadap bawahan serta mampu memotivasi guru untuk meningkatkan kinerja ${ }^{29}$.

Kepala SMP Negeri1 Konawe Selatan menyadari bahwa kepemimpinan kepala sekolah menentukan kinerja guru, sehingga praktik kepemimpinan harus tertuju pada guru. Pada saat yang sama, tentu kepala sekolah harus memberikan perhatian yang memadai pada aspek kesiswaan, tenaga kependidikan, dan infra struktur sekolah.

Kinerja guru perlu ditingkatkan karena menyangkut berbagai aspek dari citra sekolah. Pengelolaan sekolah mesti memerhatikan perbaikan kinerja guru. Kepala sekolah harus mampu memetakan kekuatan, kelemahan, peluang dan tantangan para guru yang dipimpinnya.

Upaya memastikan bahwa para guru telah melakukan kegiatan dengan baik harus diperhatikan oleh kepala sekolah, yaitu melalui proses pengawasan.

Supervisi Akademik di SMP 1 Konawe Selatan dilaksanakan oleh kepala sekolah. Dimulai dengan penyusunan program supervisi yang melibatkan wakil kepala dan guru-guru. Penyusunan program supervisi pendidikan dibuat pada awal tahun ajaran. Hal ini dimaksudkan supaya program kegiatan

\footnotetext{
${ }^{29}$ Wawancara, 12 Februari 2019
} 
supervisi dapat diintegrasikan dalam kegiatan-kegiatan sekolah secara komprehensif ${ }^{30}$.

Pelaksanaan supervisi pendidikan dilakukan setiap awal tahun pelajaran, setiap awal semester dan pada saat berlangsungnya kegiatan proses belajar mengajar. Fokus kegiatan supervisi yang dilakukan kepala sekolah dapat diidentifikasikan ke dalam dua hal yaitu; pertama, kegiatan supervisi yang menyangkut administrasi guru, dalam hal ini menyangkut semua persiapan yang harus dipersiap oleh seorang guru sebelum melakukan pembelajaran. Kegiatan supervisi yang menyangkut dengan kegiatan proses belajar mengajar.

Selanjutnya kepala sekolah SMP Negeri 1 Konawe Selatan, menjelaskan bahwa penyusunan program supervisi pendidikan dilaksanakan pada awal semester ganjil atau pada awal tahun ajaran, demikian juga pelaksanaan programnya. Sedangkan evaluasi program supervisi pendidikan dilakukan pada setiap akhir semester ganjil dan semester genap dengan tujuan dapat mengetahui sejauhmana pencapaian program supervisi yang telah dilaksanakan.

Sehubungan dengan uraian di atas, hasil wawancara dengan guru-guru menyatakan bahwa mereka mengetahui kepala sekolah telah menyusun jadwal supervisi. Sebelum melaksanakan supervisi terhadap guru-guru sudah menyusun program terlebih dahulu, jika program tidak disusun terlebih dahulu dengan baik, maka pelaksanaannya tidak sesuai dengan apa yang diharapkan. Adapun program- program yang disusun mengenai jadwal kegiatannya terdiri dari tanggal dimulai pelaksanaannya sampai akhir, alat yang diperlukan, tujuan yang ingin dicapai, rancangan untuk pengembangan kemampuan profesianal guru, meningkatkan motivasi kerja guru dan bagai mana cara agar supervisi pendidikan dapat berjalan dengan baik.

Kepala sekolah merencanakan pelaksanaan supervisi pendidikan terhadap guru-guru minimal satu kali, dan maksimal dua kali dalam setahun, yaitu satu kali pada semester ganjil dan satu kali pada semester genap. Jadwal pelaksanaannya pada awal dan akhir semester, baik semester ganjil maupun semester genap. Hal ini dilakukan untuk melihat perkembangan dan perubahan yang dilakukan guru dalam proses belajar mengajar.

\footnotetext{
${ }^{30}$ Wawancara, 12 Februari 2019
} 
Pada akhir semester genap tahun berjalan dilakukan evaluasi program supervisi pendidikan dengan tujuan dapat mengetahui sejauhmana program-program tersebut sudah terealisasi dan kegiatan-kegiatan mana yang perlu direvisi karena tidak relevan untuk dilaksanakan. Demikian juga, dapat mengidentifikasi hal-hal yang dapat menghambat proses supervisi. Selanjutnya temuan-temuan hasil evaluasi, baik terhadap program maupun terhadap hasil pelaksanaan supervisi tersebut segera ditindaklanjuti untuk memenuhi target sesuai dengan yang telah diprogramkan.

Program supervisi pendidikan yang disusun oleh kepala sekolah menjadi prioritas kegiatan sebelum proses belajar mengajar berlangsung. Menurut keterangan kepala sekolah SMP Negeri 1 Konawe Selatan supervisi terhadap guru-guru merupakan bagian dari tugas yang harus dilaksanakan oleh kepala sekolah dalam membina guru dalam proses belajar mengajar.

Sasaran supervisi pendidikan oleh kepala sekolah adalah setiap guru bidang mata pelajaran dengan tujuan untuk membina guru agar lebih terampil dan cakap dalam melaksanakan tugasnya. di samping itu, untuk mendorong guru menciptakan kreatifitas dalam proses belajar mengajar agar kegiatan tersebut dapat berlangsung secara efektif dan menyenangkan bagi siswa. Inilah sebenarnya kondisi yang diharapkan dalam proses pembelajaran di sekolah.

Pelaksanaan supervisi pendidikan yang dilakukan oleh kepala sekolah lebih menekankan pada pembinaan terhadap kemampuan guru dalam mengelola pembelajaran. Supervisi dilakukan kepala sekolah dengan cara kekeluargaan dan bukan paksaan, sehingga guru tidak merasa takut melihat supervisor datang pada saat akan disupervisi. Ini semua dilakukan untuk menjaga keharmonisan antara guru dan atasan agar saling memotivasi”.

Teknik supervisi yang sering digunakan dalam pelaksanaan supervisi di sekolah SMP Negeri 1 Konawe seletan yaitu teknik kunjungan kelas, pembicaraan individual, diskusi tentang masalahmasalah yang dihadapi guru yang berkaitan dengan pelaksanaan belajar mengajar. Salah seorang guru di SMP Negeri 1 Konawe Selatan menjelaskan bahwa teknik supervisi yang dilakukan kepala sekolah adalah dengan kunjungan kelas. Selain itu, teknik individual 
antara guru dengan supervisor juga sangat membantu guru dalam memperbaiki sistem mengajar yang lebih baik.

Kepala sekolah memiliki tanggung jawab yang sangat kompleks, disebabkan oleh beberapa komponen yang dikelolanya yaitu tenaga pendidik, kependidikan, siswa, dan kelembagaan sekolah secara keseluruhan. Kualitas layanan pendidikan yang diberikan oleh sekolah sangat ditentukan oleh kualitas sikap pada tugas yang melekat pada seorang kepala sekolah ${ }^{31}$.

Umumnya, menjadi kepala sekolah merupakan kelanjutan dari tugas-tugas keguruan. Artinya bahwa secara umum, para kepala sekolah adalah guru. Dengan posisi demikian, kepala sekolah adalah orang yang sangat memahami persoalan-persoalan pembelajaran disebabkan pengalaman keguruannya. Bahkan pada kondisi tertentu, kepala sekolah harus turun kembali ke kelas-kelas jika guru mengalami halangan tetap untuk mengajar. Sehingga sosok pendidik tetap melekat selamanya pada kepala sekolah ${ }^{32}$.

Keragaman potensi sekolah mengharuskan seorang kepala sekolah mengerahkan segenap upaya untuk melakukan pengelolaan dalam rangka tercapainya tujuan-tujuan sekolah. Tentu saja seorang kepala sekolah tidak melaksanakan tugas secara individual, tetapi melibatkan dan memberdayakan guru dan tenaga kependidikan. Tujuan-tujuan jangka panjang sekolah membutuhkan pemikiran yang cerdas, visi yang kuat, serta misi yang jelas dari pimpinan sekolah. Dalam konteks ini kepala sekolah mesti tampil sebagai pengelola yang handal, menjadi perencana, menggerakkan, dan melakukan pengendalian $^{33}$.

Problem-problem keguruan, misalnya kemangkiran, ketidaksiapan menghadapi kelas, ketidaksiapan perangkat pembelajaran, dan perilaku peserta didik, merupakan objek pengawasan kepala sekolah. Karenanya, kerja-kerja supervisi oleh kepala sekolah mesti dilakukan secara terencana, yang menggambarkan kesiapan kepala sekolah atas berbagai kondisi yang

${ }^{31}$ Nur, J. (2018). Kepala Sekolah Dan Kualitas Sikap pada Tugas. Shautut Tarbiyah, 24(2), 263-277.

${ }^{32}$ Fitrah, M. (2017). Peran kepala sekolah dalam meningkatkan mutu pendidikan. Jurnal Penjaminan Mutu, 3(1), 31-42.

${ }^{33}$ Setiyati, S. (2014). Pengaruh kepemimpinan kepala sekolah, motivasi Kerja, dan budaya sekolah terhadap kinerja guru. Jurnal Pendidikan Teknologi dan Kejuruan, 22(2), 200-206. 
mungkin dihadapi oleh sekolah terutama guru. Singkatnya, supervisi merupakan tugas yang melekat dalam kiprah kepala sekolah ${ }^{34}$.

Ketajaman visi dan kompetensi yang memadai membuat seorang kepala sekolah mampu menghadapi berbagai tantangan sekolah. Dengan modal tersebut, kepala sekolah dapat menegaskan kekuatannya dalam memengaruhi warga sekolah. Meskipun, kekuatan pengaruh harus diimbangi dengan menciptakan irama yang selaras dengan kondisi psikologis warga sekolah. Peran-peran tersebut dapat terlaksana jika kepala sekolah memposisikan dirinya sebagai pemimpinan (leader) bagi segenap warga sekolah ${ }^{35}$. Kepala sekolah yang diharapkan dalam konteks kekinian harus mampu melakukan inovasi $^{36}$, dan cerdas dalam pengalokasian sumber daya manusia dalam rangka tercapainya tujuan-tujuan sekolah ${ }^{37}$.

Inovasi-inovasi yang dihadirkan oleh kepala sekolah akan menjadi pembeda dalam kompetisi antar sekolah. Di samping itu, inovasi dibutuhkan oleh sekolah yang berada dalam masa krisis. Kepemimpinan di masa krisis sangat dibutuhkan untuk mengangkat kembali marwah sekolah dari keterpurukan ${ }^{38}$. Komitmen terhadap mutu (quality) mesti menjadi citra dari seorang kepala sekolah ${ }^{39}$, yang kemudian dituangkan dalam rencana jangka panjang sekolah ${ }^{40}$. Hal ini

34 Akib, H., \& Saleh, S. (2015). Pengaruh Kepala Sekolah Sebagai Supervisor Terhadap Kinerja Guru Di Smk Negeri 7 Makassar. Jurnal Office, 1(2), 141-147.

35 Ismayani, A. I., Niswaty, R., \& Darwis, M. (2015). Eranan Kepala Sekolah Sebagai Leader Di SMA Negeri 8 Kabupaten Bulukumba. Jurnal Ad'ministrare, 2(2), 101-107.

36 Syahrul, S. (2015). Kepemimpinan dan Inovasi Lembaga Pendidikan (Pengalaman Pondok Gontor VII Putra Sulawesi Tenggara). Al-Ta'dib, 8(1), 82-100.

37 Mukhtar, M., \& Akbar, M. (2019, December). Kiai's Leadership in Managing Human Resources. In 3rd International Conference on Education Innovation (ICEI 2019). Atlantis Press.

38 Badarwan, B. (2018). Dinamika Sekolah Pinggiran dalam Perspektif Kepemimpinan Krisis di Kota Kendari. Shautut Tarbiyah, 24(2), 181-203.

39 Syahrul, S. (2013). Penelitian sebagai Instrumen Perbaikan Kualitas Kinerja Organisasi Pendidikan secara Berkelanjutan (Continuous Improvement). AlTa'dib, 6(1), 150-163.

${ }^{40}$ Syahrul, S. (2017). Perencanaan Strategis dan Praktiknya di Perguruan Tinggi. Shautut Tarbiyah, 23(1), 142-159. 
menunjukkan kesiapan sekolah dalam menghadapi setiap perubahan yang mungkin terjadi di masa depan ${ }^{41}$.

\section{Kesimpulan}

Iklim belajar di SMP Negeri 1 Ranomeeto tercipta karena keterlibatan yang tinggi dari para guru. Faktor kemampuan, motivasi dan keterampilan sangat memengaruhi kinerja guru di SMP Negeri 1 Konawe Selatan. Peran-peran keguruan yang dilakukan oleh para guru di SMP Negeri 1 Konawe Selatan telah melampaui kewajiban kinerja mereka. Kepala sekolah menjadi penggerak dalam perluasan peran dan peningkatan kinerja guru di SMP Negeri 1 Konawe Selatan.

\section{Daftar Pustaka}

Akib, H., \& Saleh, S. (2015). Pengaruh Kepala Sekolah Sebagai Supervisor Terhadap Kinerja Guru Di Smk Negeri 7 Makassar. Jurnal Office, 1(2), 141-147.

Apriliya, S. (2007). Manajemen Kelas untuk Menciptakan Iklim Belajar yang Kondusif. Bandung: Visindo.

Ashsiddiqi, H. (2012). Kompetensi sosial guru dalam pembelajaran dan pengembangannya. Ta'dib: Journal of Islamic Education (Jurnal Pendidikan Islam), 17(01), 61-71.

Awe, E. Y., Dantes, N., \& Lasmawan, M. P. P. I. W. (2019). Hubungan Antara kualifikasi akademik, kompetensi, motivasi kerja dengan kinerja guru sekolah dasar (SD) di Kecamatan Bajawa, Kabupaten Ngada (Doctoral dissertation, Ganesha University of Education).

Badarwan, B. (2018). Dinamika Sekolah Pinggiran dalam Perspektif Kepemimpinan Krisis di Kota Kendari. Shautut Tarbiyah, 24(2), 181-203.

Bungin, B. (2007). Penelitian kualitatif: komunikasi, ekonomi, kebijakan publik, dan ilmu sosial lainnya. Kencana.

BUYUNG NASUTIYON, W. I. S. N. U. (2010). Pengaruh Sertifikasi Guru terhadap Kompetensi Mengajar Guru Sekolah Dasar

${ }^{41}$ Syahrul, S. (2016). Readines Frame: Analisis Kerangka Kesiapan dalam Transformasi Pendidikan Tinggi (Pengalaman Iain Kendari). Al-Ta'dib, 9(1), 162181. 
Negeri di Kecamatan Benjeng Kabupaten Gresik. Jurnal Mahasiswa Teknologi Pendidikan, 1(1).

Danuputra, F., \& Sary, F. P. (2019). Pengaruh Dimensi Knowledge Sharing Terhadap Kinerja Karyawan (studi Pada Karyawan Non-dosen Universitas Telkom Bandung). eProceedings of Management, 6(2).

Febriyanti, B. M., \& Faslah, R. (2013). Hubungan Antara Beban Kerja Dengan Kinerja Pada Karyawan Balai Permasyarakatan Kelas I Jakarta Selatan (BAPAS) di Jakarta Timur. Jurnal Pendidikan Ekonomi Dan Bisnis (JPEB), 1(2), 104-116.

Fitrah, M. (2017). Peran kepala sekolah dalam meningkatkan mutu pendidikan. Jurnal Penjaminan Mutu, 3(1), 31-42.

Fiteriani, I. (2015). Membudayakan Iklim Semangat Belajar Pada Siswa Sekolah Dasar. TERAMPIL: Jurnal Pendidikan dan Pembelajaran Dasar, 2(1), 115-25.

Hadinata, P. (2012). Iklim kelas dan motivasi belajar siswa SMA. Jurnal psikologi, 3(1).

Hasanah, D. S., Fattah, N., \& Prihatin, E. (2010). Pengaruh Pendidikan Latihan (Diklat) Kepemimpinan Guru dan Iklim Kerja Terhadap Kinerja Guru Sekolah Dasar Se Kecamatan Babakancikao Kabupaten Purwakarta. Jurnal Penelitian Pendidikan, 11(2), 90-105.

Indrawati, Y. (2006). Faktor-faktor yang mempengaruhi kinerja guru matematika dalam pelaksanaan kurikulum berbasis kompetensi (kbk) pada sekolah menengah atas Kota Palembang. Jurnal Manajemen \& Bisnis Sriwijaya, 4(7), 41-58.

Ismayani, A. I., Niswaty, R., \& Darwis, M. (2015). Eranan Kepala Sekolah Sebagai Leader Di SMA Negeri 8 Kabupaten Bulukumba. Jurnal Ad'ministrare, 2(2), 101-107.

Miles, M. H., \& Huberman, A. A. 1984. Qualitative Data Analysis. Beverly Hills.

Milkan, A. (2018). Pengaruh Kewibawaan Guru Pendidikan Agama Islam Terhadap Akhlak Siswa Di Sekolah Menengah Atas Negeri 2 Tualang Kabupaten Siak (Doctoral dissertation, Universitas Islam Negeri Sultan Syarif Kasim Riau).

Mukhtar, M., \& Akbar, M. (2019, December). Kiai's Leadership in Managing Human Resources. In 3rd International Conference on Education Innovation (ICEI 2019). Atlantis Press. 
Murwati, H. (2012). Pengaruh sertifikasi profesi guru terhadap motivasi kerja dan kinerja guru di smk negeri se-Surakarta.

Nugraha, Y. (2015). Pengaruh Kinerja Guru PKn dan Iklim Belajar Terhadap Perkembangan Sikap Disiplin Peserta Didik (Studi Survey Pada Sekolah Menengah Pertama Negeri di Kabupaten Karawang) (Doctoral dissertation, Universitas Pendidikan Indonesia).

Nur, J. (2018). Kepala Sekolah Dan Kualitas Sikap pada Tugas. Shautut Tarbiyah, 24(2), 263-277.

Pramudyo, A. (2010). Analisis faktor-faktor yang mempengaruhi kinerja dosen negeri pada kopertis Wilayah V Yogyakarta. Jurnal Bisnis: Teori dan Implementasi, 1(1), 1-11.

Rochman, C., \& Gunawan, H. (2011). Pengembangan Kompetensi kepribadian guru: Menjadi guru yang dicintai dan diteladani oleh siswa. Bandung: Nuansa Cendekia.

Sastramayani, S. (2018). Mempertemukan Semesta Guru dan Peserta Didik dalam Metode Pembelajaran Kooperatif. Shautut Tarbiyah, 24(2), 308-333.

Sastriyani, S. (2018). Dinamika Pembelajaran PAI di Era Digital (Studi di MTsN Wawotobi, Kabupaten Konawe). Shautut Tarbiyah, 24(1), 145-162.

Sauri, S. (2010). Membangun karakter bangsa melalui pembinaan profesionalisme guru berbasis pendidikan nilai. Jurnal Pendidikan Karakter, 2(2), 1-15.

Setiyati, S. (2014). Pengaruh kepemimpinan kepala sekolah, motivasi Kerja, dan budaya sekolah terhadap kinerja guru. Jurnal Pendidikan Teknologi dan Kejuruan, 22(2), 200-206.

Sugiyono, P. Dr. 2010. Metode Penelitian Kuantitatif, Kualitatif, dan R\&D. Bandung: CV Alfabeta.

Suhandani, D., \& Julia, J. (2014). Identifikasi Kompetensi Guru Sebagai Cerminan Profesionalisme Tenaga Pendidik Di Kabupaten Sumedang (Kajian Pada Kompetensi Pedagogik). Mimbar Sekolah Dasar, 1(2), 128-141.

Susilo, S. V. (2018). Refleksi nilai-nilai pendidikan ki hadjar dewantara dalam upaya upaya mengembalikan jati diri pendidikan indonesia. Jurnal Cakrawala Pendas, 4(1).

Syahrul, S. (2015). Dinamika Pembelajaran Metodologi Penelitian Pada Mahasiswa Jurusan Tarbiyah Stain Kendari. Al-Izzah: Jurnal Hasil-Hasil Penelitian, 8(1), 193-211. 
Syahrul, S. (2015). Kepemimpinan dan Inovasi Lembaga Pendidikan (Pengalaman Pondok Gontor VII Putra Sulawesi Tenggara). AlTa'dib, 8(1), 82-100.

Syahrul, S. (2013). Penelitian sebagai Instrumen Perbaikan Kualitas Kinerja Organisasi Pendidikan secara Berkelanjutan (Continuous Improvement). Al-Ta'dib, 6(1), 150-163.

Syahrul, S. (2017). Perencanaan Strategis dan Praktiknya di Perguruan Tinggi. Shautut Tarbiyah, 23(1), 142-159.

Syahrul, S. (2016). Readines Frame: Analisis Kerangka Kesiapan dalam Transformasi Pendidikan Tinggi (Pengalaman Iain Kendari). Al-Ta'dib, 9(1), 162-181.

Wardana, D. S. (2013). Motivasi berprestasi dengan kinerja guru yang sudah disertifikasi. Jurnal Ilmiah Psikologi Terapan, 1(1), 98109.

Widayaningtyas, R. (2016). Pengaruh Disiplin Kerja dan Motivasi Kerja terhadap Kinerja Karyawan (Studi Pada PT. Macanan Jaya Cemerlang Klaten). Jurnal Manajemen Bisnis Indonesia (JMBI), 5(5), 527-537.

Zulkifli, M., Darmawan, A., \& Sutrisno, E. (2014). Motivasi Kerja, Sertifikasi, Kesejahteraan dan Kinerja Guru. Persona: Jurnal Psikologi Indonesia, 3(02). 